Institute of $\mathbf{F}_{\text {ood and }} \mathbf{A}_{\text {gricultural }} \mathbf{S}_{\text {ciences }}$

\title{
Economic Impacts of Healthcare in the Rural Health Networks of Florida ${ }^{1}$
}

Effie Philippakos, Alan W. Hodges, and David Mulkey²

\section{Introduction}

\section{Healthcare in Regional Economies}

The healthcare sector is important to state and regional economies, particularly in rural areas where it is a major employer second only to public schools. Healthcare is also an important element of rural economic development. Quality healthcare services and facilities help attract new businesses to an area and retain existing firms. Indeed, healthcare quality in a community may be a critical factor for businesses investigating potential locations. It is also a major consideration for retirees, which is significant in Florida since the state attracts many retirees.

The healthcare sector, as with any basic industry, has both direct and secondary economic impacts. Direct economic impacts include output, employment, and value added contributions directly associated with healthcare providers. These businesses make purchases from other regional suppliers, which experience increased sales and employment as a result (indirect effects).

Subsequently, the income accruing to employees in the region from direct and indirect activities leads to increased spending by regional households (induced effects).

For example, in the case of a local hospital, the facility employs staff and provides medical services in exchange for monetary payment (direct impacts). The hospital also purchases inputs from other regional businesses such as office and medical suppliers (indirect impacts). Workers from hospitals and complementary businesses, whose jobs are supported by the hospital, make personal consumption expenditures to grocery stores, restaurants, and the like (induced impacts). These impacts are magnified if the hospital purchases inputs predominantly from regional businesses and receives service payments from sources located outside the region. The total impact to the regional economy is the sum of the direct, indirect, and induced effects.

\section{Florida's Rural Health Networks}

This report summarizes the economic impacts of existing healthcare institutions in Florida's eight Rural Health Networks. A list of Florida counties included in each Rural Health Network is provided in Table 1 . Note that only a portion of the counties of

1. This is EDIS document FE 339, a publication of the Department of Food and Resource Economics, Florida Cooperative Extension Service, Institute of Food and Agricultural Sciences, University of Florida, Gainesville, FL. Published July 2002. Please visit the EDIS website at http://edis.ifas.ufl.edu. 2. Effie Philippakos, research assistant; Alan W. Hodges, Assistant-In FRE; and David Mulkey, Professor; Department of Food and Resource Economics, Florida Cooperative Extension Service, Institute of Food and Agricultural Sciences, University of Florida, Gainesville, FL.

The use of trade names in this publication is solely for the purpose of providing specific information. UF/IFAS does not guarantee or warranty the products named, and references to them in this publication does not signify our approval to the exclusion of other products of suitable composition.

The Institute of Food and Agricultural Sciences is an equal opportunity/affirmative action employer authorized to provide research, educational information and other services only to individuals and institutions that function without regard to race, color, sex, age, handicap, or national origin. For information on obtaining other extension publications, contact your county Cooperative Extension Service office. Florida Cooperative Extension Service/Institute of Food and Agricultural Sciences/University of Florida/Christine Taylor Waddill, Dean. 
Alachua, Clay, Escambia, Leon, Martin, Palm Beach, St. Johns, and Santa Rosa are part of a Rural Health Network. Additionally, the economic impacts of healthcare institutions in Florida counties that are not part of a Rural Health Network were estimated for comparison.

This study is part of a larger project involving compilation of data pertinent to Rural Health Network planners, including demographic information, economic indicators, number of healthcare providers and facilities, and community health status in addition to the economic impact analysis featured in the present study (http://economicimpact.ifas.ufl.edu, 2001).

\section{Methodology}

\section{Healthcare Sector Definition}

Five economic sectors make up the healthcare industry and are analyzed in this report:

1. Doctors and dentists.

2. Nursing and protective care.

3. Hospitals.

4. Other medical services.

\section{Pharmaceuticals.}

The doctors and dentists sector includes offices and clinics of doctors of medicine, dentists, doctors of osteopathy, chiropractors, optometrists, and podiatrists. Nursing and protective care includes skilled nursing care and intermediate care facilities. The hospital sector includes general medical, surgical, psychiatric, and other specialty hospitals. Other medical services include medical and dental laboratories, home health care services, kidney dialysis centers, and other specialty outpatient facilities. The pharmaceutical sector represents pharmaceutical-related sales by drug stores.

\section{Data Sources}

A variety of data sources were used for this analysis. Data for Doctors and Dentists, and Other Medical Services were obtained from Implan data for Florida counties (MIG, 2001). Output data for the
Hospitals and Nursing and Protective Care sectors were provided by the Florida Agency for Health Care Administration. Revenue information on drugstore retail sales were provided by the Florida Department of Revenue. Since drugstores sell non-pharmaceutical products as well, 50 percent of drugstore sales were estimated to represent pharmaceutical sales, based on market research data (Florida Trend Magazine, 2001). Industry output associated with retail drug sales was estimated using an average gross margin of 0.267 for Florida drug stores (U.S. Census Bureau).

\section{Economic Impact Analysis}

An input-output (I-O), social accounting matrix framework was used to estimate the direct, indirect, and induced economic impacts of the healthcare industry in Florida. Input-output analysis is a technique that captures the regional economic interdependence between different industries, households and government institutions (Miller and Blair, 1985; Mulkey and Hodges, 2000). Specifically, it describes the relationship between economic sectors and the final demand for goods and services, including purchases for final consumption by households, businesses and government, capital investment, and exports to buyers outside the region. The premise of input-output analysis is that the structure of the economy is technologically fixed, such that for a given change in the final demand, output, or employment for a particular industry or region, there will be predictable changes in other linked sectors of the economy. These changes are measured by estimating the regional economic multipliers associated with the particular industry, using a matrix inversion procedure applied to the matrix of inter-industry transactions. Input-output models have proven useful to policymakers, industry officials, and others interested in estimating regional impacts attributed to economic activity by specific sector(s) and have been applied to a wide array of research problems such as assessing the importance of agriculture, evaluating the economic structure of rural communities, and investigating the economic repercussions of plant openings.

The input-output analysis was conducted using the IMPLAN PRO ${ }^{\mathrm{TM}}$ software package and associated 
databases for Florida counties (MIG, 1999). The

IMPLAN database offers economic and

sociodemographic descriptions for all United States

counties across 528 economic sectors that correspond

to the U.S. Department of Commerce four digit

Standard Industrial Classification (SIC) system. The

software component of the IMPLAN modeling

system performs calculations for a pre-defined study

area to assess economic impacts to the region.

Multipliers are available from IMPLAN for economic output, total value added, employment, employee compensation, personal income, other proprietary income, and indirect business taxes and are provided for direct, indirect, and induced impact effects.

IMPLAN was used to estimate the total economic impacts associated with Florida's healthcare sector by multiplying the value of output against the direct effects multiplier and multiplying non-local funding values (health insurance-covered expenditures) against the indirect and induced effects multipliers and subsequently summing as indicated in Figure 1.

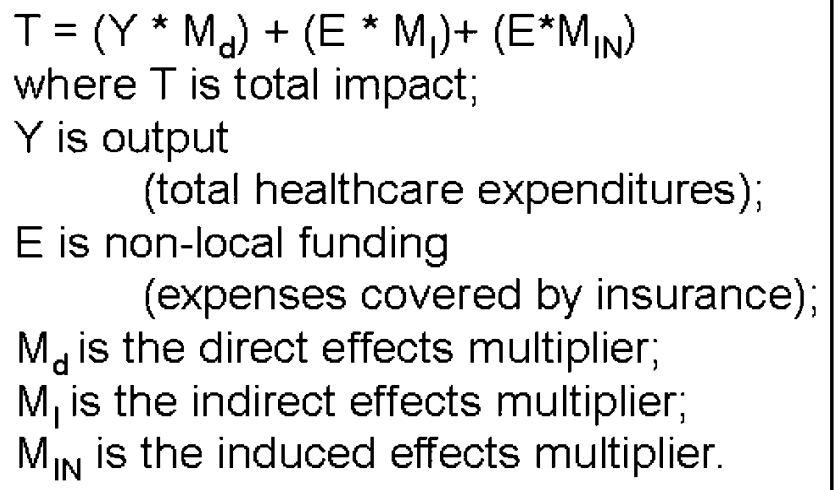

Figure 1. Total economic impact calculation.

Economic impacts were estimated for the measures of output, value added, and employment. Value added represents the value of output less the value of inputs used by firms in the production of a good or service (COGS). It is a measure of income and is a useful economic indicator because it avoids the double counting of expenditures on intermediate and final goods inherent in output measures.

\section{Local Versus Non-Local Funding}

For the current study, output represents the value of total healthcare expenditures in the region and non-local funding represents the portion of healthcare expenditures covered by health insurance, including Medicare and Medicaid. Expenditures covered by insurance are assumed to be a non-local funding source, and out-of-pocket patient expenses not covered by insurance are assumed to be internal to the region. Non-local funding represented 77.9 percent of output, based on personal communications with the Florida Department of Health.

\section{Regional Population Adjustments}

A number of Florida counties have only a portion of their area as part of a Rural Health Network, including Alachua, Clay, Escambia, Leon, Martin, Palm Beach, Santa Rosa, St. Johns, and Volusia Counties. However, the IMPLAN model does not classify regions on a sub-county level. This could lead to an overestimation of economic impacts if both the urbanized and rural portions of these counties are included in Rural Health Network county definitions. In order to more accurately estimate economic impacts, county populations were expressed as a proportion of rural populations, as indicated by the 1990 Bureau of the Census, and health expenditures were then adjusted downward proportional to the reduction in county populations. As an example, according to the 1990 Bureau of the Census, 34.2 percent of Alachua County's population was rural. Total county health expenditures were multiplied by 34.2 percent to reflect the portion of health expenditures attributed to rural residents. Per-capita economic impact estimates were based on these adjusted population levels. Total impact values for the state of Florida include both the urbanized and rural portions of all Rural Health Network counties in addition to the non-Rural Health Network counties. Therefore, state totals are greater than the sum of impacts for non-Rural Health Network counties and Rural Health Networks.

\section{Findings}

The total economic impacts of the healthcare services sector in the Rural Health Networks of Florida include $\$ 13.9$ billion in output, 222,836 jobs, and $\$ 9.1$ billion in value added. These impacts were considerably lower than those estimated for the non-Rural Health Network counties of Florida, amounting to $\$ 123.2$ billion in output, 1.8 million 
jobs, and $\$ 80.4$ million in value added. Total per-capita output impacts were $\$ 6,928$ in the Rural Health Networks of Florida and $\$ 11,502$ in the non-Rural Health Network counties of Florida. The fact that non-Rural Health Network counties receive greater impacts on a total and per-capita basis is not surprising, given that greater populated areas attract proportionately higher levels of economic activity. Two Rural Health Network regions had particularly low economic impacts in relation to the population base: the Panhandle and Rural Health Network of Monroe County. The Heartland, Lake Okeechobee, and Northwest Florida Rural Health Networks had relatively higher economic impacts.

\section{Output Impacts}

Total output impacts across all healthcare sectors in the Rural Health Networks of Florida totaled \$13.9 billion (Table 2). By comparison, the non-Rural Health Network counties generated $\$ 123.2$ billion in total output impacts. The Heartland Rural Health Network had the largest output impacts ( $\$ 5.5$ billion) followed by Northwest Florida ( $\$ 2.4$ billion), St. Johns River ( $\$ 1.8$ billion), Health Partnership of North Central Florida (\$1.4 billion), Lake Okeechobee ( $\$ 1.2$ billion), Big Bend ( $\$ 825.7$ million), Rural Health Network of Monroe County (\$421.8 million), and the Panhandle Area Health Network (\$404.7 million). Among all Rural Health Networks, the Hospital sector accounted for the majority of total output impacts (70 percent), followed by Doctors and Dentists (13 percent), Nursing and Protective Care (nine percent), Other Medical Services (seven percent), and Pharmaceuticals (one percent).

\section{Employment Impacts}

Annual total employment impacts related to the healthcare sector of the Rural Health Networks of Florida were 222,836 jobs (Table 3). By comparison, the non-Rural Health Network counties of Florida had total employment impacts of 1.8 million jobs. The Heartland Rural Health Network had the largest employment impacts $(87,117$ jobs), followed by Northwest Florida (39,111 jobs), St. Johns River (29,862 jobs), Health Partnership of North Central Florida (23,043 jobs), Lake Okeechobee (17,211 jobs), Big Bend (12,954 jobs), Panhandle Area
(6,895 jobs), and the Rural Health Network of Monroe County (6,643 jobs). Among all Rural Health Networks, the Hospital sector captured the majority of total employment impacts (65 percent), followed by Nursing and Protective Care (13 percent), Doctors and Dentists (12 percent), Other Medical Services (eight percent), and Pharmaceuticals (two percent).

\section{Value Added Impacts}

The healthcare services sector in the Rural Health Networks of Florida generated annual total value added impacts of $\$ 9.1$ billion (Table 4 ). By comparison, the non-Rural Health Network counties of Florida yielded total value added impacts of $\$ 80.4$ billion. The Heartland Rural Health Network had the largest value added impacts at $\$ 3.6$ billion, followed by Northwest Florida ( $\$ 1.6$ billion), St. Johns River ( $\$ 1.2$ billion), Health Partnership of North Central Florida (\$915.3 million), Lake Okeechobee (\$785.9 million), Big Bend (\$481.7 million), Rural Health Network of Monroe County (\$279.1 million), and the Panhandle Area Health Network (\$276.2 million). Among all Rural Health Networks, the Hospital sector accounted for the majority of total output impacts (68 percent), followed by Doctors and Dentists sector (14 percent), Nursing and Protective Care (10 percent), Other Medical Services (seven percent), and Pharmaceuticals (one percent).

\section{Per-Capita Output Impacts}

Given the wide range in overall size of the Rural Health Network regions of Florida, economic impacts are more meaningfully expressed on a per-capita basis. For example, the Rural Health Network of Monroe County consists of only one county, whereas the Lake Okeechobee Rural health Network consists of five counties. Total per-capita output impacts were $\$ 6,928$ among all healthcare sectors in the Rural Health Networks of Florida (Table 5). The Doctors and Dentists sector had per-capita output impacts of $\$ 1723$, the Nursing and Protective Care sector had $\$ 550$, Hospitals claimed \$4139, Other Medical Services were $\$ 444$, and Pharmaceuticals had $\$ 71$ in per-capita output impacts. Total per-capita output impacts were $\$ 11,502$ for the non-Rural Health Network counties across all sectors. Lake Okeechobee had the greatest per-capita output 
impacts at $\$ 8,287$, followed by Northwest Florida

$(\$ 7,817)$, Heartland $(\$ 7,726)$, Health Partnership of

North Central Florida $(\$ 6,620)$, St. Johns River

$(\$ 5,884)$, Big Bend $(\$ 5,502)$, Rural Health Network

of Monroe County $(\$ 5,217)$, and the Panhandle Area

Health Network $(\$ 3,948)$.

\section{References}

Rural Health Network data reports. (2002).

Available on the World Wide Web at

http://economicimpact.ifas.ufl.edu.

Minnesota Implan Group. (2001). Stillwater, MN: MIG, Inc.

Florida Trend Magazine. (September 2001).

U.S. Census Bureau. (2000). Annual benchmark

report for retail trade and food services. Washington, D.C.

Miller, R.E., and P.D. Blair. (1985).

Input-output analysis: Foundations and extensions.

Englewood Cliffs, NJ: Prentice-Hall Publishers.

Mulkey, W.D., and A.W. Hodges. (2000). Using IMPLAN to assess local economic impacts.

Extension Digital Information Source (EDIS) FE168, University of Florida, Gainesville, FL. Available on the World Wide Web at http://edis.ifas.ufl.edu/FE168.

IMPLAN Professional, Version 2.0. (1999). Social Accounting and Impact Analysis Software, User's Guide, Analysis Guide, and Data Guide.

Stillwater, MN: MIG, Inc. 
Table 1. Counties in the Rural Health Networks of Florida.

\begin{tabular}{|c|c|c|}
\hline Name of Agency & $\begin{array}{c}\text { Number of } \\
\text { Counties }\end{array}$ & Names of Counties Within Agency \\
\hline Big Bend Rural Health Network & 6 & $\begin{array}{l}\text { Gadsden, Jefferson, Leon, }{ }^{*} \text { Madison, Taylor, } \\
\text { and Wakulla }\end{array}$ \\
\hline Health Partnership of North Central Florida & 8 & $\begin{array}{l}\text { Alachua, }{ }^{*} \text { Bradford, Dixie, Gilchrist, Hamilton, } \\
\text { Levy, Suwannee, and Union }\end{array}$ \\
\hline Heartland Rural Health Network & 5 & $\begin{array}{l}\text { Charlotte, DeSoto, Hardee, Highlands, and } \\
\text { Polk }\end{array}$ \\
\hline Lake Okeechobee Rural Health Network & 5 & $\begin{array}{l}\text { Glades, Hendry, Martin, }{ }^{*} \text { Okeechobee, and } \\
\text { Palm Beach* }\end{array}$ \\
\hline Northwest Florida Rural Health Network & 4 & $\begin{array}{l}\text { Escambia, }{ }^{*} \text { Okaloosa, Santa Rosa, }{ }^{*} \text { and } \\
\text { Walton }\end{array}$ \\
\hline Panhandle Area Health Network & 5 & $\begin{array}{l}\text { Calhoun, Holmes, Jackson, Liberty, and } \\
\text { Washington }\end{array}$ \\
\hline Rural Health Network of Monroe County & 1 & Monroe \\
\hline St. Johns River Rural Health Network & 6 & $\begin{array}{l}\text { Baker, Clay, }{ }^{*} \text { Flagler, Putnam, St. Johns, }{ }^{*} \text { and } \\
\text { Volusia* }\end{array}$ \\
\hline Non-Rural Health Network Counties & 27 & $\begin{array}{l}\text { Bay, Brevard, Broward, Citrus, Collier, } \\
\text { Columbia, Duval, Franklin, Gulf, Hernando, } \\
\text { Hillsborough, Indian River, Lafayette, Lake, } \\
\text { Lee, Manatgee, Marion, Miami-Dade, Nassua, } \\
\text { Orange, Osceola, Pasco, Pinellas, St. Lucie, } \\
\text { Sarasota, Seminole, and Sumter }\end{array}$ \\
\hline & & \\
\hline
\end{tabular}


Table 2. Total output impacts in the Rural Health Networks of Florida (\$ millions), 1998-99.

\begin{tabular}{|c|c|c|c|c|c|c|}
\hline Rural Health Network & $\begin{array}{l}\text { Doctors \& } \\
\text { Dentists }\end{array}$ & $\begin{array}{c}\text { Nursing \& } \\
\text { Protective } \\
\text { Care }\end{array}$ & Hospitals & $\begin{array}{l}\text { Other } \\
\text { Medical } \\
\text { Services }\end{array}$ & $\begin{array}{l}\text { Pharma- } \\
\text { ceuticals }\end{array}$ & $\begin{array}{c}\text { Total } \\
\text { Healthcare } \\
\text { Sectors }\end{array}$ \\
\hline & \multicolumn{6}{|c|}{ (\$ millions) } \\
\hline $\begin{array}{l}\text { Big Bend Rural Health } \\
\text { Network }\end{array}$ & 182.7 & 176.1 & 411.3 & 48.3 & 7.3 & 825.7 \\
\hline $\begin{array}{l}\text { Health Partnership of } \\
\text { North Central Florida }\end{array}$ & 317.5 & 96.3 & 823.8 & 136.1 & 8.0 & $1,381.7$ \\
\hline $\begin{array}{l}\text { Heartland Rural Health } \\
\text { Network }\end{array}$ & $1,405.1$ & 360.4 & $3,357.1$ & 292.9 & 54.9 & $5,470.4$ \\
\hline $\begin{array}{l}\text { Lake Okeechobee } \\
\text { Rural Health Network }\end{array}$ & 282.3 & 71.4 & 735.7 & 92.3 & 13.0 & $1,194.7$ \\
\hline $\begin{array}{l}\text { Northwest Florida } \\
\text { Rural Health Network }\end{array}$ & 624.1 & 122.8 & $1,511.9$ & 154.4 & 21.3 & $2,434.5$ \\
\hline $\begin{array}{l}\text { Panhandle Area Health } \\
\text { Network }\end{array}$ & 105.9 & 78.3 & 194.8 & 23.0 & 2.7 & 404.7 \\
\hline $\begin{array}{l}\text { Rural Health Network } \\
\text { of Monroe County, } \\
\text { Florida }\end{array}$ & 86.1 & 20.9 & 270.9 & 28.6 & 15.3 & 421.8 \\
\hline $\begin{array}{l}\text { St. Johns River Rural } \\
\text { Health Network }\end{array}$ & 457.4 & 178.4 & $1,009.1$ & 117.1 & 20.1 & $1,782.1$ \\
\hline $\begin{array}{l}\text { Total Rural Health } \\
\text { Networks }\end{array}$ & $3,461.1$ & $1,104.6$ & $8,314.6$ & 892.7 & 142.6 & $13,915.6$ \\
\hline $\begin{array}{l}\text { Non-Rural Health } \\
\text { Network Counties in } \\
\text { Florida }\end{array}$ & $32,214.9$ & $6,703.9$ & $74,556.4$ & $8,265.0$ & $1,454.6$ & $123,194.8$ \\
\hline Total Florida* & $41,748.4$ & $9,607.3$ & $94,488.4$ & $10,802.1$ & $2,898.8$ & $162,545.0$ \\
\hline
\end{tabular}


Table 3. Total employment impacts in the Rural Health Networks of Florida (jobs), 1998-99.

\begin{tabular}{|c|c|c|c|c|c|c|}
\hline Rural Health Network & $\begin{array}{l}\text { Doctors \& } \\
\text { Dentists }\end{array}$ & $\begin{array}{l}\text { Nursing \& } \\
\text { Protective } \\
\quad \text { Care }\end{array}$ & Hospitals & $\begin{array}{l}\text { Other } \\
\text { Medical } \\
\text { Services }\end{array}$ & $\begin{array}{l}\text { Pharma- } \\
\text { ceuticals }\end{array}$ & $\begin{array}{l}\text { Total } \\
\text { Healthcare } \\
\text { Sectors }\end{array}$ \\
\hline & \multicolumn{6}{|c|}{ (jobs) } \\
\hline $\begin{array}{l}\text { Big Bend Rural Health } \\
\text { Network }\end{array}$ & 2,432 & 4,258 & 5,173 & 892 & 199 & 12,954 \\
\hline $\begin{array}{l}\text { Health Partnership of } \\
\text { North Central Florida }\end{array}$ & 4,466 & 2,385 & 13,466 & 2,513 & 213 & 23,043 \\
\hline $\begin{array}{l}\text { Heartland Rural Health } \\
\text { Network }\end{array}$ & 18,394 & 8,385 & 54,041 & 4,942 & 1,355 & 87,117 \\
\hline $\begin{array}{l}\text { Lake Okeechobee } \\
\text { Rural Health Network }\end{array}$ & 3,163 & 1,505 & 10,874 & 1,412 & 257 & 17,211 \\
\hline $\begin{array}{l}\text { Northwest Florida } \\
\text { Rural Health Network }\end{array}$ & 8,221 & 2,880 & 24,827 & 2,685 & 498 & 39,111 \\
\hline $\begin{array}{l}\text { Panhandle Area Health } \\
\text { Network }\end{array}$ & 1,395 & 1,836 & 3,200 & 400 & 64 & 6,895 \\
\hline $\begin{array}{l}\text { Rural Health Network } \\
\text { of Monroe County, } \\
\text { Florida }\end{array}$ & 1,106 & 463 & 4,240 & 495 & 339 & 6,643 \\
\hline $\begin{array}{l}\text { St. Johns River Rural } \\
\text { Health Network }\end{array}$ & 6,187 & 4,236 & 16,821 & 2,109 & 509 & 29,862 \\
\hline $\begin{array}{l}\text { Total Rural Health } \\
\text { Networks }\end{array}$ & 45,364 & 25,948 & 132,642 & 15,448 & 3,434 & 222,836 \\
\hline $\begin{array}{l}\text { Non-Rural Health } \\
\text { Network Counties in } \\
\text { Florida }\end{array}$ & 394,139 & 136,927 & $1,113,813$ & 127,577 & 28,430 & $1,800,886$ \\
\hline Total Florida* & 513,976 & 204,248 & $1,469,454$ & 169,830 & 61,362 & $2,418,870$ \\
\hline
\end{tabular}


Table 4. Total value added* impacts in the Rural Health Networks of Florida (\$ millions), 1998-99.

\begin{tabular}{|c|c|c|c|c|c|c|}
\hline Rural Health Network & $\begin{array}{l}\text { Doctors \& } \\
\text { Dentists }\end{array}$ & $\begin{array}{l}\text { Nursing \& } \\
\text { Protective } \\
\text { Care }\end{array}$ & Hospitals & $\begin{array}{l}\text { Other } \\
\text { Medical } \\
\text { Services }\end{array}$ & $\begin{array}{l}\text { Pharma- } \\
\text { ceuticals }\end{array}$ & $\begin{array}{l}\text { Total } \\
\text { Healthcare } \\
\text { Sectors }\end{array}$ \\
\hline & \multicolumn{6}{|c|}{ (\$ millions) } \\
\hline $\begin{array}{l}\text { Big Bend Rural Health } \\
\text { Network }\end{array}$ & 124.5 & 126.8 & 195.5 & 29.1 & 5.8 & 481.7 \\
\hline $\begin{array}{l}\text { Health Partnership of } \\
\text { North Central Florida }\end{array}$ & 212.6 & 68.4 & 546.2 & 81.9 & 6.2 & 915.3 \\
\hline $\begin{array}{l}\text { Heartland Rural Health } \\
\text { Network }\end{array}$ & 927.5 & 252.7 & $2,156.8$ & 177.0 & 42.0 & $3,556.0$ \\
\hline $\begin{array}{l}\text { Lake Okeechobee } \\
\text { Rural Health Network }\end{array}$ & 191.1 & 50.4 & 477.6 & 56.9 & 9.9 & 785.9 \\
\hline $\begin{array}{l}\text { Northwest Florida } \\
\text { Rural Health Network }\end{array}$ & 433.0 & 88.5 & $1,007.5$ & 96.9 & 16.7 & $1,642.6$ \\
\hline $\begin{array}{l}\text { Panhandle Area Health } \\
\text { Network }\end{array}$ & 73.5 & 56.4 & 129.8 & 14.4 & 2.1 & 276.2 \\
\hline $\begin{array}{l}\text { Rural Health Network } \\
\text { of Monroe County, } \\
\text { Florida }\end{array}$ & 57.4 & 15.0 & 177.7 & 17.2 & 11.8 & 279.1 \\
\hline $\begin{array}{l}\text { St. Johns River Rural } \\
\text { Health Network }\end{array}$ & 299.7 & 124.8 & 642.7 & 69.1 & 15.3 & $1,151.8$ \\
\hline $\begin{array}{l}\text { Total Rural Health } \\
\text { Networks }\end{array}$ & $2,319.3$ & 783.0 & $5,333.8$ & 542.5 & 109.8 & $9,088.4$ \\
\hline $\begin{array}{l}\text { Non-Rural Health } \\
\text { Network Counties in } \\
\text { Florida }\end{array}$ & $21,385.5$ & $4,673.5$ & $48,135.9$ & $5,089.4$ & $1,086.5$ & $80,370.8$ \\
\hline Total Florida** & $27,813.2$ & $6,735.0$ & $62,736.9$ & $6,638.4$ & $2,195.9$ & $106,119.4$ \\
\hline
\end{tabular}


Table 5. Total per-capital output impacts in the Rural Health Networks of Florida, 1998-99.

\begin{tabular}{|c|c|c|c|c|c|c|}
\hline Rural Health Network & $\begin{array}{c}\text { Doctors \& } \\
\text { Dentists }\end{array}$ & $\begin{array}{l}\text { Nursing \& } \\
\text { Protective } \\
\text { Care }\end{array}$ & Hospitals & $\begin{array}{l}\text { Other } \\
\text { Medical } \\
\text { Services }\end{array}$ & $\begin{array}{l}\text { Pharma- } \\
\text { ceuticals }\end{array}$ & $\begin{array}{l}\text { Total } \\
\text { Healthcare } \\
\text { Sectors }\end{array}$ \\
\hline & \multicolumn{6}{|c|}{ (dollars) } \\
\hline $\begin{array}{l}\text { Big Bend Rural Health } \\
\text { Network }\end{array}$ & 1,217 & 1,173 & 2,741 & 322 & 49 & 5,502 \\
\hline $\begin{array}{l}\text { Health Partnership of } \\
\text { North Central Florida }\end{array}$ & 1,521 & 461 & 3,947 & 652 & 38 & 6,620 \\
\hline $\begin{array}{l}\text { Heartland Rural Health } \\
\text { Network }\end{array}$ & 1,984 & 509 & 4,741 & 414 & 78 & 7,726 \\
\hline $\begin{array}{l}\text { Lake Okeechobee } \\
\text { Rural Health Network }\end{array}$ & 1,958 & 495 & 5,103 & 640 & 90 & 8,287 \\
\hline $\begin{array}{l}\text { Northwest Florida } \\
\text { Rural Health Network }\end{array}$ & 2,004 & 394 & 4,855 & 496 & 68 & 7,817 \\
\hline $\begin{array}{l}\text { Panhandle Area Health } \\
\text { Network }\end{array}$ & 1,033 & 764 & 1,900 & 224 & 26 & 3,948 \\
\hline $\begin{array}{l}\text { Rural Health Network } \\
\text { of Monroe County, } \\
\text { Florida }\end{array}$ & 1,065 & 258 & 3,351 & 354 & 189 & 5,217 \\
\hline $\begin{array}{l}\text { St. Johns River Rural } \\
\text { Health Network }\end{array}$ & 1,510 & 589 & 3,332 & 387 & 66 & 5,884 \\
\hline $\begin{array}{l}\text { Total Rural Health } \\
\text { Networks }\end{array}$ & 1,723 & 550 & 4,139 & 444 & 71 & 6,928 \\
\hline $\begin{array}{l}\text { Non-Rural Health } \\
\text { Network Counties in } \\
\text { Florida }\end{array}$ & 3,008 & 626 & 6,961 & 772 & 136 & 11,502 \\
\hline Total Florida* & 2,800 & 644 & 6,539 & 725 & 194 & 10,903 \\
\hline $\begin{array}{l}\text { Source: MIG, Florida De } \\
{ }^{*} \text { Florida totals reflect the } \\
\text { Health Network counties }\end{array}$ & $\begin{array}{l}\text { ent of Reve } \\
\text { nized and ru }\end{array}$ & $\begin{array}{l}\text { Agency for } \\
\text { Dortions of all }\end{array}$ & $\begin{array}{l}\text { Care } \mathrm{Ad} \\
\text { I Health } \mathrm{N}\end{array}$ & ration. & $n$ to & Rural \\
\hline
\end{tabular}

